\title{
Building Cross-Cultural Competence in a Foreign Language through Technology-Enhanced Project-Based Learning
}

\author{
Written by: \\ Anastasiia Syzenko ${ }^{144}$ \\ https://orcid.org/0000-0001-8443-7813 \\ Yana Diachkova ${ }^{145}$ \\ https://orcid.org/0000-0003-3145-6695
}

\begin{abstract}
In contemporary changing and innovative academic and working environment, tertiary schools need to rethink their approach to teaching and learning by gearing it towards the skills in most demand. Innovation in any sphere becomes more and more dependent on the collaboration between actors from very different backgrounds who combine their own expertise to create something new. This happens both on an individualas well as on an institutional level. The organizations of the future will be forced to work more and more closely with people and institutional partners from all over the world in order to bring as many different perspectives and areas of expertise together as possible. This means that cross-cultural competence becomes one of the crucial factors in building a competitive profile of a prospective specialist. Therefore, this paper explores approaches to building cross-cultural competence using the English language as a tool and presents the findings of a pilot training on experimental collaborative cross-cultural project implemented with Master level Economics students in Ukraine. Qualitative and quantitative methods were used to collect the data and examine participants' language proficiency. The findings suggest that participation in collaborative technology-enhanced cross-cultural projects has a significant positive effect on learners' language proficiency and develops their cross-cultural competence facilitating development of productive skills on the basis of receptive ones.
\end{abstract}

Keywords: cross-cultural competence, project-based learning, collaborative project, foreign language learning.

\section{Introduction}

With growing need to adjust higher education curricula to the changing demands of employers and ensure successful acquisition of skills required for aspiring professionals, foreign language education is currently undergoing a number of changes aimed at making it more efficient, relevant and innovative. Since the main purpose of learning a foreign language is to enable learners to effectively communicate with representatives of other cultures, it should be taught as a means of cross-cultural communication (Erling 2005; Jenkins 2006; Kilickaya 2009). Cross-cultural communication involves a comparison of interactions among people from the same culture to those from another culture. In our research context, language learners are taught English for specific purposes (ESP). Introduction of cross-cultural competence into the ESP syllabi makes them more aware of their own business culture in order to be tolerant to the business culture of other countries. Although linguistic accuracy is necessary for language users to communicate effectively, when language "is used in contexts of communication, it is bound up with culture in multiple and complex ways" (Kramsch 1998:3). Thus, development of cross-cultural competence allows ESP students not only to study a particular

\footnotetext{
${ }^{144} \mathrm{PhD}$ in Linguistics, Associate Professor in Department of Foreign Languages of the Faculty of Economics of Taras Shevchenko National University of Kyiv. Ukraine

${ }^{145} \mathrm{PhD}$ in Education, Assistant Professor at Department of Foreign Languages of the Faculty of Economics of Taras Shevchenko National University of Kyiv. Ukraine
} 
idea or concept within many cultures but also to be engaged in intercultural communication that is a symbolic, interpretative, transactional, contextual process which implies the engagement of culturally-different professionals (Myron W. and Koester J., 1993).

Foreign languages and communication skills are listed among the top requirements for various employment opportunities around the world. In Ukraine, in particular, ability to communicate effectively in English and/or other foreign language is seen as a considerable competitive advantage on the job market. According to the World Bank comprehensive publication on skills needed for a modern Ukraine, foreign languages, communication and teamwork are listed among "skills requirements frequently cited in job vacancies" (Del Carpio et al, 2017:4). Understanding the cultural context of both the target language and the learners' native language leads to greater awareness of the interdependent relationship between languages and cultures.

Recently, cross-cultural competence has been in focus of instructors in foreign language classrooms (Liaw 2006; Van Hook 2011). Crosscultural communication is not just an encounter between cultures; it should "be viewed and analyzed as a complex process" (Stier 2006:5). Researchers have suggested an impressive array of cross-cultural communicative education models (Deardorff 2006; Spitzberg \& Changnon 2009; Stier 2006; Leask 2015). Michael Byram authored one of the most influential ones, which incorporates holistic linguistic and cross-cultural competence and has clear, practical, and ethical objectives (Byram 1997). According to the scholar, the aims of cross-cultural language teaching are 'to develop learners' cross-cultural competence as well as linguistic competence; to prepare them for interaction with people of other cultures; to enable them to understand and accept people from other cultures as individuals with other distinctive perspectives, values and behaviors; and to help them to see that such interaction is an enriching experience" (Byram, Gribkova, \& Starkey, 2002:10).

In Ukraine, foreign language curriculum at a tertiary level usually aims at developing communicative competence within a certain professional field. However, due to limited number of hours allocated for the discipline, the focus is mainly on the development of receptive skills, mainly reading, and acquisition of fieldspecific vocabulary. Self-study often aims at further developing students' receptive skills and grammar drills, whereas productive skills and competences in presenting information, reasoning and independent thinking, creative approach to solving a given task are mostly neglected. Lack of opportunities for authentic language use often results in learners' gaining extensive knowledge about the target language (know what) while they are weak in using the language in a meaningful way (know how). In addition, Ukraine is a monocultural country with $77.5 \%$ of the population being ethnic Ukrainians and $17.2 \%$ - Russians (whose business culture is pretty much similar to Ukrainian one). This used to challenge the necessity to be cross-culturally aware for an average Ukrainian in working environment. A solution to these challenges requires a comprehensive revision of curriculum and a thoughtful incorporation of various multimodal and multicultural components in the educational process in order to create authentic learning situations where the real world becomes a part of the educational experience and necessitates the use of an authentic language by the learners thus developing their productive skills.

Studies suggest that technology plays an important role in creating authentic language learning environments that promote and facilitate language learning (Thorne 2005). It touches upon implementation of project activity into the context of language learning and teaching and allows maintaining essential contextual conditions in a foreign language classroom. This helps learners develop their language skills further (both in terms of learning and practicing the language features that are learned in the classroom), and they can become fluent speakers of the language. Thus, the paper looks at effective approaches to foreign language teaching to improve learners' language proficiency and develop their cross-cultural competence through participation in crosscultural projects based on authentic learning situations, as well as at effective correlation between classroom, self-study and content-based learning in terms of participants' time and efforts.

\section{Methodology, findings, and discussion}

Ukrainian students report that one of the fundamental difficulties they encounter while learning a foreign language is a lack of opportunities to experience interactive crosscultural communication in a target language. At the higher education level, there are a number of other constraints to successful building of linguistic and intercultural competence. In Ukraine, languages generally taught at tertiary level include English, German, French and 


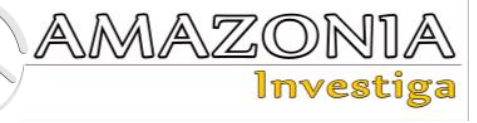

Spanish with English being predominant around Ukraine (88\% of all language classes offered at higher education institutions). Recently, there has been a growth in Polish and Chinese language courses that are mostly taught as optional courses. However, a primary issue is a very limited number of language classes envisaged for non-linguistic majors, e.g. two eighty-minute classes per week during first three semesters amounting to 9 ECTS at Bachelor level and another 3 ECTS foreign language course at Master level. Secondly, there is a problem with students' motivation in learning languages due to a) high workload for their major-related disciplines; b) low level of intrinsic motivation with regard to learning a foreign language; c) lack of understanding of the importance of language skills for future employment. Finally, as there is no minimum language requirement for taking a language course and a relatively low average level of language skills among school graduates entering universities, the level of language proficiency reached by the end of the course is usually below the required B2+ level by the Common European Framework of Reference for Languages.

To address language-learning problem and its possible solutions in the Ukrainian context as well as to involve transactions between the person and the environment, this action research explored a technology-enhanced, collaborative cross-cultural (hereinafter, X-culture) project that was completed by two groups of university students. The research consisted in analyzing the impact of students' participation in collaborative $\mathrm{X}$-culture project on their language proficiency and cross-cultural competence, and the aim of the research was to demonstrate that technologyenhanced, X-culture projects whose primary aim is not necessarily language learning per se do provide a more realistic context of communication, which is rarely achievable with other instructional models. And this realistic context in its turn enhances the development of productive skills facilitating learners' receptive activities. X-culture project gives an opportunity to create an environment where the knowledge is created through the transformation of experience, i.e. "from the combination of grasping and transforming experience" (Kolb, 1984:41).

$\mathrm{X}$-Culture is a large-scale international experiential learning project that involves over 3,500 MBA and business students from 100 universities from 40 countries on six continents every semester. The students are placed in global virtual teams of seven to eight persons, each student coming from a different country. X- culture is a non-commercial project for universities and professionals that is built around the idea of solving business cases based on teamwork, collaboration and the wisdom of a crowd. Teams are randomly assigned a case study to solve and are composed of students coming from different countries. Students are expected to show competency by taking part in a number of online discussions. The aim is to provide the learners with as many opportunities as possible to use the target language for meaningful communication in authentic environment and scaffold their learning process. Working with people from around the globe and dealing with cultural differences, time-zone dispersion, and global communication challenges, the teams complete a consulting project for a multinational company.

This paper looks at the findings of a pilot training held with 22 Master's students majoring in Economics who participated in a five-month XCulture project as part of their core disciplines. The pilot training touched upon interdisciplinary approach to ESP teaching trough content and language integrated learning. Although the ultimate aim of the X-Culture project is to solve a business case and present a team-based report with the solution, there are many positive side effects of participating in this project and our pilot training focuses on its implications for the ESP learners' language skills and cross-cultural competence. Therefore, the aim of the pilot training was to measure a positive impact of content and language integrated learning based on X-Culture project on the improvement of English learners' language proficiency and development of their cross-cultural competence. Primarily, it is useful to outline the structure and organisation of the X-Culture project. Firstly, project participants come from a variety of cultures and the language of interaction during the project is English that contributes greatly into the development of English language communicative competence. Secondly, the provision of the context, similar to the real workplace, makes cross-cultural international settings very real. The geographic and time-zone dispersion, cultural and language differences were real. Finally, the study task and environment are designed to resemble the corporate world as closely as possible. The team members interact daily for eight to nine weeks, which is a typical project length in the corporate world. The task of the X-Culture project involves market research, market entry plan development, and product design. The project is supervised by instructors with rich business consulting 
experience and managed as a regular business consulting project.

In order to assess the impact of participation in the X-culture project on ESP learners' language proficiency and cross-cultural competence we used three main research tools. The first one consisted in quantitatively measuring students' language skills by testing them at the beginning of the course and at the end of the X-culture project. In the second part of our study, we designed questionnaires to evaluate students' attitudes towards the communication component of the X-Culture course and analyzed students' responses. Finally, we held semi-structured interviews - that give greater flexibility to find out more about participants' thoughts, feelings, and opinions - with randomly selected 11 students to investigate how they perceive the impact of participating in the course on their language proficiency and cross-cultural competence.

Two language tests administered at the beginning and at the end of the pilot training focused both on productive and receptive skills with a major emphasis on productive skills, i.e. speaking and writing. Tests were anonymous and their results were not used in any form of assessment. Average scores in the language test before and after the X-Culture project, are presented in Table 1.

Table 1. Language Skills Test Scores of Students Participating in X-Culture Project

\begin{tabular}{lllll}
\hline & Reading & Listening & Speaking & Writing \\
\hline Test 1 & 82.3 & 67.3 & 75.5 & 71.0 \\
Test 2 & 87.7 & 69.1 & 79.9 & 76.2 \\
& +5.4 & +1.8 & +4.4 & +5.2 \\
\hline
\end{tabular}

Overall, the results of the test clearly show an improvement along all the four skills with the highest improvement observed in reading and writing skills. This can be explained by the fact that students needed to read and analyze a lot of information in target language in order to complete the project's tasks and prepare a written report as the final assessment of the project. Students reported that they also peer-reviewed each other's written assignments which also contributed to their reading and writing skills development. Speaking average scores also show a significant improvement with students also reporting increased confidence as a result of continuous online communication with other participants of the X-culture project. Even though all the communication was held in the online chat, students demonstrated improved scores in spoken interaction and communication patterns.
The questionnaire designed to evaluate students' attitudes towards the language communication component of the X-Culture project was distributed among 22 students and all of them submitted their responses. The responses are presented in Table 2. The distribution of responses show that the majority of students agrees or strongly agrees that the course has had a positive impact on their cross-cultural competence and language proficiency and expressed a positive attitude to the course itself. They also see the importance of the project and the skills it allows to practice for their future careers and find this type of project motivating. This gives ground to make a conclusion that participation of students in projects of this kind greatly benefits their communicative and crosscultural competences, improves communication skills and has a positive impact on motivation to learn a foreign language.

Table 2. Students' Attitudes towards the Communication Component of X-Culture Project

\begin{tabular}{llllll}
\hline & $\begin{array}{l}\text { Strongly } \\
\text { Agree }\end{array}$ & Agree & $\begin{array}{l}\text { Somewhat } \\
\text { agree }\end{array}$ & Disagree & $\begin{array}{l}\text { Strongly } \\
\text { disagree }\end{array}$ \\
\hline $\begin{array}{l}\text { I like this type of training } \\
\begin{array}{l}\text { involving communication with } \\
\text { foreign students. }\end{array}\end{array}$ & 15 & 5 & 1 & 1 & 0 \\
\hline
\end{tabular}


The training enables us to use English in realistic situations.

I find communication with foreign students motivating.

I can see the improvement in my communication skills.

3

12

5

1

1

The course helped me to learn more about different cultures.

I can see the importance of this training for my future career.
14 3
In the questionnaire, all students agreed that XCulture project created opportunities for learning about cultures, including their own and other participants'. In order to make the questionnaire more robust and assess participants' crosscultural competence and experience throughout the project, we adopted Byram's ICC model to structurize the questionnaire in an appropriate way. By means of this model as a "combination of knowledge, skills, attitudes and awareness which allow a speaker, to varying degrees to recognize, understand, interpret and accept other ways of living and thinking beyond his or her home culture" (Beacco and Byram, 2007), we measured the level of participants' cross-cultural competence development. It shall be assumed that through participation in the project students developed their cross-cultural competence and communication skills in all four dimensions (see Table 3), i.e. knowledge of their own and their counterparts' cultures, open attitudes towards cross-cultural exchanges, skills for interacting with foreigners, and a critical cultural awareness necessary to evaluate cultures.

Due to the nature of the X-Culture project, all teams are cross-cultural with randomly selected participants of different cultural backgrounds. We concentrated on the exploration of participants' subjective viewpoints and on gathering in-depth accounts of students' experiences. Analyzing the data, we looked into the dimensions we coded before, and tried to find the subjects' perspectives on each of them. Looking beyond that, our ESP students' answers are a cue to their group's ethos and beliefs. Therefore, students reported that they worked in teams of four to six with students from different countries and cultures, including the USA, Mexico, France, Germany, Brazil, Chile, Spain, etc. During the interviews, students reflected on this cross-cultural experience and their responses indicated that not only their knowledge about cultures was largely acquired but also their speaking skills dramatically improved through the process of interaction, which is one of the main advantages of the X-Culture project, as they had an opportunity to contribute to discussions for deeper understanding of issues relevant to their topics or, in some cases, for deeper understanding of the task requirement. While culture-related communication was not a primary aim of the project, students discovered different cultures through other participants' communication styles, their attitude to time and duties, and their perceptions of other cultures. Students reported that most of their critical cultural awareness was developed through online interaction with other team participants. Students experienced an intensive compare/contrast process both in individual and group interactions. 
Table 3. Students' Development of Cross-Cultural Competence (based on Byram's ICC Model)

\begin{tabular}{|c|c|c|}
\hline Dimensions & Students' reflections & \\
\hline Knowledge: & $\begin{array}{l}\text {...of one's own culture and the } \\
\text { interlocutors' culture }\end{array}$ & $\begin{array}{l}\text { The project broadened my horizons. I learned } \\
\text { more about different cultures and attitudes to } \\
\text { life and business. (S2) } \\
\text { It [the project] helped me understand how } \\
\text { different our culture is. (S6) } \\
\text { I know much more about different countries } \\
\text { now, I want to go there. (S4) }\end{array}$ \\
\hline $\begin{array}{l}\text { Cross-cultural } \\
\text { attitudes: }\end{array}$ & $\begin{array}{l}\text { Curiosity and openness to } \\
\text { learn about one's own culture } \\
\text { and the interlocutors' culture }\end{array}$ & $\begin{array}{l}\text { I'd like to have more opportunities to } \\
\text { communicate with people from other countries } \\
\text { and cultures. It is such an enriching experience. } \\
\text { (S1) } \\
\text { I enjoyed most our communication not related to } \\
\text { the project... when we talked about our } \\
\text { families, friends, cities. (S2) } \\
\text { I wish we had more projects like this from the } \\
\text { beginning of the study. (S5) }\end{array}$ \\
\hline $\begin{array}{l}\text { Discovery and } \\
\text { interaction skills: }\end{array}$ & $\begin{array}{l}\text { The ability to acquire new } \\
\text { knowledge of a culture } \\
\text { through synchronous } \\
\text { interaction }\end{array}$ & $\begin{array}{l}\text { Online communication was awesome. } \\
\text { Sometimes we spent nights talking about the } \\
\text { project. (S2) } \\
\text { Continuous communication was critical for } \\
\text { successful completion of the project. (S3) }\end{array}$ \\
\hline $\begin{array}{l}\text { Critical cultural } \\
\text { awareness: }\end{array}$ & $\begin{array}{l}\text { The ability to evaluate a } \\
\text { culture }\end{array}$ & $\begin{array}{l}\text { It was hard sometimes. Especially when some } \\
\text { participants did not respect the deadlines... } \\
\text { never respected them. And thought it was } \\
\text { normal. (S4) } \\
\text { I realised that they were much better prepared } \\
\text { for doing such tasks. They were taught at school } \\
\text { and then trained at university. (S1) }\end{array}$ \\
\hline
\end{tabular}

Since participants in the X-Culture project must exchange ideas frequently, it builds authentic cross-cultural communication for all the active participants. This also makes a significant contribution into learners own business culture awareness. The project facilitates active learning that requires a problem-solving orientation, a critical approach, and the ability to evaluate information. As learning also requires social skills, it means that learners are expected to acquire the skills that will enable them to take part in effective social interaction. Active learning theories stress the social elements of learning, e.g. the importance of co-operative action, collaborative problem-solving and sharing as tools for attaining deeper processes of learning - and in many cases also for achieving better results. This means participation in discussions, dialogues and mutually shared reflections, working in responsible cooperation with other learners. Learner participation is fostered by a supportive atmosphere and equal partnership among the learners, based on cooperation and trust. This combination of active learning and project-based learning within XCulture project has proved an effective tool for building students' skills in both project management and cross-cultural communication, and students themselves had mostly appreciated the latter. They report improved language productive skills, increased confidence and greater awareness of other cultures.

Based on the findings and students' feedback analysis, the advantages of technology-enhanced $\mathrm{X}$-Culture project for language learning and development of cross-cultural competence can be derived. Thus, X-Culture project:

- has real world relevance

- provides an opportunity for the participants to examine the task from different cultural perspectives

- provides multiple opportunities to collaborate, to critically and creatively solve problems (the case), and to 
communicate, thus developing the $21 \mathrm{st}$ century skills

- provides an opportunity to reflect on the experience

- leads beyond domain- and skill-specific outcomes

- makes the participants aware of cultural similarities and differences

- is conductive to both learning and communicating

- provides motivation for further selfdevelopment

- allows to develop communicative skills through the fusion of receptive and productive skills.

The findings of this research suggest that participation in cross-cultural business projects involving synchronous communication and interaction greatly affects students' motivation and improves their linguistic and cross-cultural competence. The way cross-cultural competence is developed may vary according to different factors; however, our study shows the significant advantages of technology-enhanced, projectbased learning.

\section{Conclusions}

The findings suggest that when a learning activity is linked with an authentic task, this combination fosters the development of a competence in focus. In particular, participation in the X-Culture project not only promoted learning and increased interest in the language but also provided authentic opportunities for students to develop their language skills and cross-cultural competence. Students acknowledged that they improved their communication skills and learned collaboration; test proved that students improved their receptive and productive skills in a foreign language (English). Project-based learning in crosscultural setting proves to be an effective means of developing students' communicative and cross-cultural competences.

Today, online educational communities provide diverse collaboration projects around the world and the study found that participation in such projects promotes language-learning motivation and helps learners develop active attitudes towards language learning and intercultural communication. Moreover, as this study has shown, such projects help students develop a range of skills essential for their employability by providing multiple opportunities to use the target language in context. Higher order thinking skills also developed as learners were provided with opportunities to analyse and discuss others' work and make judgments on how to improve it. Consequently, the findings suggest that crosscultural learning environment promoted the use of the target language as a tool to convey messages adequately, both in written and spoken form, and facilitated learning new linguistic elements in context. Another key implication of authentic activities is that the cross-cultural learning environment lent itself to close the gap between language acquired in foreign language learning settings and the real world.

This research investigated the impact of only one cross-cultural project and future studies should investigate the results of integrating other types of projects into higher education curriculum in Ukraine.

\section{References}

Beacco, J. C., \& Byram, M. (2007). From linguistic diversity to plurilingual education: Guide for the development of language education policies in Europe. Strasbourg, France: Council of Europe Publishing. Language Policy Division. Byram, M. (1997). Teaching and assessing intercultural communicative competence. Clevedon, UK: Multilingual Matters

Byram, M. (2012). Language awareness and (critical) cultural awareness- relationships, comparisons and contrasts. Language Awareness, 21(1-2), 5-13.

Byram, M., Gribkova, B, \& Starkey, H. (2002). Developing the intercultural dimension in language teaching. A practical introduction for teachers. Strasbourg, France: Council of Europe Publishing, Language Policy Division.

Council of Europe (2014). Developing Intercultural Competence in Education. Strasbourg: Council of Europe Pestalozzi Series (3).

Deardorff, D. K. (2006). Identification and assessment of intercultural competence as a student outcome of internationalization. Journal of Studies in International Education, 10(3), 241-266.

Gonzalez-Perez, M. A., Cathro, V., Caprar, D. V., \& Taras, V. (2014). Virtual Teams and International Business Teaching and Learning: The Case of the Global Enterprise Experience (GEE). Journal of Teaching in International Business, 25(3), 200-213.

Del Carpio, X., Kupets, O., Muller N., Olefir, A. (2017). Skills for a Modern Ukraine. Directions in Development--Human Development; Washington, DC: World Bank.

Harmer J. (2011). To teach English is human, to teach CLIL is divine? Retrivered Septenber 11, 
2019

from

https://jeremyharmer.wordpress.com/2011/01/2 5/to-teach-english-is-human-to-teach-clil-isdivine/comment-page-1/

Jenkins, J. (2006). Current perspectives on teaching world Englishes and English as a lingua franca. TESOL Quarterly, 4O(1), pp. 157-181.

Kilickaya, F. (2009). World Englishes, English as an international language and applied linguistics. English Language Teaching, 2(3), 35-38.

Kramsch, C. (1998). Language and culture. Oxford, UK: Oxford University Press.

Kolb, D.A. (1984). Experiential learning: Experience as the source of learning and development (Vol. 1): Prentice-Hall Englewood Cliffs, NJ. Retrieved January 12, 2019 from https://www.researchgate.net/profile/David_Kol b/publication/235701029_Experiential_Learnin g_Experience_As_The_Source_Of_Learning_A nd_Development/links/00b7d52aa908562f9f000 000/Experiential-Learning-Experience-As-TheSource-Of-Learning-And-Development.pdf Leask, B. (2015). Internationalizing the Curriculum. New York: Routledge.

Liaw, M. (2006). E-learning and the development of intercultural competence. Language Learning \& Technology, 10(3), 49-64. Retrieved January 01, 2019 from http://lt.msu.edu/vol10num3/liaw/default.html
Myron W. L., Koester J. (1993). Intercultural Competence: Interpersonal Communication Across Cultures. HarperCollins College Publishers, $346 \mathrm{p}$.

O'Dowd, R. (2007). Evaluating the outcomes of online intercultural exchange. ELT Journal, 61(2), 144-152.

Spitzberg, B., \& Changnon, G. (2009). Conceptualizing intercultural competence. In D. K. Deardorff (Ed.), The Sage handbook of intercultural competence, Thousand Oaks, CA: Sage, 2-52.

Stier, J. (2006). Internationalisation, intercultural communication and intercultural competence. Journal of Intercultural Communication, 11(1), pp. 1-12.

Thorne, S.L. (2005). Internet-mediated intercultural foreign language education: Approaches, pedagogy, and research. CALPER Working Paper Series No. 6. The Pennsylvania State University, Center for Advanced Language Proficiency Education and Research.

Van Hook, S.R. (2011). Modes and models for transcending cultural differences in international classrooms. Journal of Research in International Education, 10(1), 5-27. Retrieved January 27, 2019 from

27. http://jri.sagepub.com/content/10/1/5 